\title{
Humoral immune response in dogs and cats vaccinated against rabies in southeastern Brazil
}

\author{
Avelino Albas ${ }^{1 *}$, Miléia Ricci Picolo ${ }^{1}$, Célio Nereu Soares ${ }^{2}$, Hugo Vagner Ulbano Bachega ${ }^{3}$ \\ and Mário Hissamitsu Tarumoto ${ }^{4}$
}

\begin{abstract}
Background: Brazil holds annual nationwide public campaigns to vaccinate dogs and cats against rabies. The presence of rabies antibodies in these animals, which are among the main transmitters of rabies to humans, is a good indicator that they are immunized and protected.

Methods: In the present study we analyzed 834 serum samples from dogs and cats from the Southeast of Brazil (Presidente Prudente and Dracena cities), 12 months after the 2009 vaccination campaign. We used the technique known as rapid fluorescent focus inhibition test (RFFIT) and considered reactant those sera with values higher 0.5 $\mathrm{IU} / \mathrm{mL}$.
\end{abstract}

Results and discussion: Reactant sample results in Presidente Prudente were 153 (51.0\%) for dogs and 59 (32.6\%) for cats, and in Dracena 110 (52.1\%) for dogs and 71 (50.0\%) for cats. We discussed vaccine coverage of animals involved in this experiment, and observed low titers $<0.5 \mathrm{IU} / \mathrm{mL}$, especially in cats from Presidente Prudente.

Conclusion: According to the results presented in our experiment, we suggest that titers below $0.5 \mathrm{IU} / \mathrm{mL}$ are worrisome and that, for multiple reasons, animals should be immunized against rabies in the period between public vaccination campaigns. Hence, the desired vaccine coverage was not accomplished, especially among cats from Presidente Prudente.

Keywords: Rabies, Vaccination, Dogs, Cats, Humoral immune response

\section{Background}

Rabies is an acute infectious disease that affects mammals. The causative agent is a virus that replicates and spreads via peripheral nerves to the central nervous system, where it passes to the salivary glands. It has a fatal prognosis and many humans and other animals are at risk of contagion $[1,2]$.

For many decades, rabies has been considered a public health problem on all continents, except for Antarctica [3]. The disease spread even to Australia, where it became endemic in 1996 [4,5]. Some countries, such as the USA and some European nations, have been able to keep the cycle of urban rabies under control, except for sporadic transmission by wild animals [6,7]. According to the report entitled Boletin: Vigilancia Epidemiológica de la Rabia en las Américas [8], dogs were the agents

\footnotetext{
* Correspondence: avealbas@yahoo.com.br

'São Paulo Agency for Agribusiness Technology (APTA), Presidente Prudente, São Paulo State, Brazil

Full list of author information is available at the end of the article
}

responsible for $73.7 \%$ of the 60 cases of human rabies reported in the Americas in 2001; by contrast, only in North America did domestic feline cases exceed those in Latin America.

Given sufficient political will, infrastructure, economic stability, and continuous control measures, canine rabies has been significantly decreased or even eliminated in large areas, especially in South America $[9,10]$.

Having been authorized by the Brazilian Ministry of Health in 1995 to diagnose rabies, the laboratory Polo da Alta Sorocabana - located in Presidente Prudente, southwestern São Paulo state (2207'04”S; $\left.51^{\circ} 22^{\prime} 57^{\prime \prime} \mathrm{W}\right)$ carried out a survey from 1996 to 2003 that recorded 16 positive cases in cattle versus 58 in non-hematophagous bats; the fact that the last two years of the survey, 2002 and 2003, showed the highest indices evidences the spread of rabies in the region [11].

Since the 1950s, studies have shown the importance of rabies antibodies to protect vaccinated people and

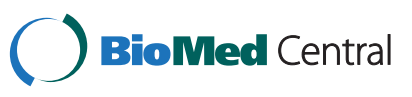


other animals. Determining the quantity of antibodies helps estimate the resistance to the rabies virus [12].

The World Health Organization [13] considers a titer $\geq$ $0.5 \mathrm{IU} / \mathrm{mL}$ an indicator for evaluating the efficacy of a rabies vaccine used in humans or animals. The most commonly used test is the rapid fluorescent focus inhibition test (RFFIT) developed by Smith et al. [14].

For many years, Presidente Prudente held the status of a rabies-free zone, as it did not present any positive cases. However, the July 2001 death of a 53-year-old woman diagnosed with the disease in Dracena led to an intensive epidemiological assessment in the region. Fragments of her central nervous system were submitted to postmortem diagnosis in the Pasteur Institute in São Paulo, which identified the rabies virus. After thorough epidemiological investigation, it was concluded that rabies had been transmitted to the victim, Mrs. IMM, by her own cat. The antigenic typing revealed variant 3 of Desmodus rotundus (common vampire bat). The vampire bat probably transmitted the virus to a non-hematophagous bat, which transmitted it to the cat. This virus variant has been isolated from several species, including dogs, cats, herbivores and non-vampire bats [15].

Hence, further studies are needed to assess antibody levels in dogs and cats supposedly vaccinated during the mass campaign carried out in Presidente Prudente and Dracena, given that the population is under serious risk of contagion on account of the close relationship between these potential zoonosis-transmitting animals and humans.

\section{Methods}

\section{Rapid fluorescent focus inhibition test (RFFIT)}

We determined the titers of neutralizing antibodies in individuals by seroneutralization in BHK21 clone 13 cells. This test, based on RFFIT and the fluorescence inhibition microtest (FIMT) was performed in 96-well polystyrene microplates (Corning, USA) [16]. The test, standardized in the Polo da Alta Sorocabana Laboratory, was adapted by Favoretto et al. [17], and carried out as follows: horse serum from the Butantan Institute of São Paulo was employed, containing $200 \mathrm{IU} / \mathrm{mL}$, and the working lot was diluted at the ratio 1:1000. The rabies virus strain PV at a 1:20 dilution was used as well as the anti-nucleocapsid conjugate acquired from the Pasteur Institute of São Paulo diluted 1:80. The reading of the microplate was performed under an inverted immunofluorescence microscope (Olympus, USA).

\section{Sera of animals (Dogs and Cats)}

We collected samples from dogs and cats residing in Presidente Prudente and Dracena 12 months after the mass vaccination, which occurred in 2009 using the Fuenzalida-Palacios antirabies vaccine. To collect the sera from these animals, the laboratory partnered with the Zoonosis Control Center of Presidente Prudente and Dracena, and the samples were prepared and stored in a freezer at $-20^{\circ} \mathrm{C}$ until use.

\section{Results and Discussion}

In the current study, 834 serum samples from dogs and cats from Presidente Prudente and Dracena were analyzed 12 months after the vaccination campaign of 2009. RFFIT was used and those sera with values higher than or equal to $0.5 \mathrm{IU} / \mathrm{mL}$ were considered reactive. In Presidente Prudente, we obtained 153 (51.0\%) reactive samples from dogs and 50 (32.6\%) from cats, whereas in Dracena we obtained $110(52.1 \%)$ and 71 (50.0\%) reactive samples, respectively, from dogs and cats (Table 1).

Based on a Pearson chi-squared test, the differences were considered significant when $\mathrm{p}<0.05$. We observed significant differences $(\mathrm{p}<0.0001)$ in the percentages of reactive sera between dogs and cats from Presidente Prudente. We also found significant differences in feline sera between Presidente Prudente and Dracena $(\mathrm{p}=0.0015)$.

In Presidente Prudente, our results showed that the percentages between dogs with reactive $(51.0 \%)$ and non-reactive sera (49.0\%) did not differ significantly. But among cats the percentage with reactive sera (32\%) was far below that of non-reactive sera (67.4\%). These differences may be attributable to the fact that cats were brought by the local population to vaccination campaigns less frequently than dogs.

In Dracena, we found no significant differences in the percentages of reactive sera between dogs and cats. But the proportion of reactive feline sera differed between the cities of Dracena (50.0\%) and Presidente Prudente (32.6\%), probably because of greater public awareness among the population of Dracena, who routinely vaccinated their cats.

Rigo and Honer [18] found similar results when analyzing 333 canine sera before the mass vaccination in 2003 in Campo Grande, state of Mato Grosso do Sul, Midwestern Brazil, and found a reactivity proportion of approximately $50 \%$.

Table 1 Humoral immune response in cats and dogs vaccinated against rabies in Dracena and Presidente Prudente, southeastern Brazil, using the RFFIT test*

\begin{tabular}{lllll}
\hline City & Animal & \multicolumn{2}{c}{ RFFIT* $^{*}$} & Total (\%) \\
\cline { 3 - 4 } & & $\begin{array}{l}\text { Reactive** } \\
\text { (\%) }\end{array}$ & $\begin{array}{l}\text { Non-reactive } \\
\text { (\%) }\end{array}$ & \\
\hline Pres. Prudente & Dog & $153(51.0)$ & $147(49.0)$ & $300(36.0)$ \\
\cline { 2 - 5 } & Cat & $59(32.6)$ & $122(67.4)$ & $181(21.7)$ \\
\hline Dracena & Dog & $110(52.1)$ & $101(47.9)$ & $211(25.3)$ \\
\cline { 2 - 5 } & Cat & $71(50.0)$ & $71(50.0)$ & $142(17.0)$ \\
\hline Total & & $393(47.1)$ & $441(52.9)$ & $834(100.0)$ \\
\hline
\end{tabular}

*RFFIT: rapid fluorescent focus inhibition test.

**Values $\geq 0.5 \mathrm{IU} / \mathrm{mL}$. 
On the other hand, Almeida et al. [19] found that most dogs had an inadequate titer $(0.5 \mathrm{IU} / \mathrm{mL}) 12$ months after vaccination, with only $26.2 \%$ of sera reactive in São Paulo versus 25\% in Paulínia, southeastern Brazil. However, better results were obtained when samples were collected thirty days after vaccination with reactivity proportions of $64 \%$ in São Paulo and $72.7 \%$ in Paulinia.

According to Aubert [20], the animals with insufficient titers developed rabies after the exposure test, which shows that animals without adequate immunity levels can develop the disease if exposed to the virus.

The specific role that domestic cats play in the spread of zoonosis is still poorly elucidated, given that the main public campaigns are focused on dogs, whose population exceeds that of cats [10].

It is necessary to take into account particular aspects of cat behavior, namely that they prey on bats and, therefore, may easily spread the rabies virus and lead to cases of human rabies [15].

In relation to the interaction between domestic cat behavior and rabies, Genaro [21] highlighted three important aspects: the population increase of cats in Brazil and other countries, especially in North America; the need to improve the strategy for vaccine coverage of cats during public campaigns; and handling difficulties focused on the owner as well as on the health agent.

\section{Conclusions}

According to the results presented in our experiment, we suggest that titers below $0.5 \mathrm{IU} / \mathrm{mL}$ are worrisome and that, for multiple reasons, animals should be immunized against rabies in the period between public vaccination campaigns. Hence, the desired vaccine coverage was not accomplished, especially among cats from Presidente Prudente.

\section{Ethics committee approval}

All procedures of the present study were performed in accordance with ethical principles of animal experimentation established by the Brazilian College of Animal Experimentation (COBEA).

\section{Competing interests}

The authors declare that there are no competing interests.

\section{Authors' contributions}

AA: project coordinator. MRP: performed the tests. CNS: responsible for collecting samples in Presidente Prudente. HVUB: responsible for collecting samples in Dracena. MHT: responsible for the statistical analysis. All authors read and approved the final manuscript.

\section{Acknowledgments}

The authors would like to thank the State of São Paulo Research Foundation (FAPESP) for its funding of this research (grant number 08/54266-3), and Célio Nereu Soares and Hugo Vagner Ulbano Bachega for collecting samples from dogs and cats.

\section{Author details}

'São Paulo Agency for Agribusiness Technology (APTA), Presidente Prudente, São Paulo State, Brazil. 'Z Zoonosis Control Center, Presidente Prudente, São Paulo State, Brazil. ${ }^{3}$ Zoonosis Control Center, Dracena, São Paulo State, Brazil. ${ }^{4}$ Department of Statistics, School of Science and Technology, São Paulo State University (UNESP - Univ Estadual Paulista), Presidente Prudente, São Paulo State, Brazil.

Received: 19 March 2013 Accepted: 12 July 2013

Published: 30 July 2013

\section{References}

1. Kristensson K, Olsson Y: Diffusion pathways and retrograde axonal transport of protein tracers in peripheral nerves. Prog Neurobiol 1973, 1:87-109.

2. Charlton KM: The pathogenisis of rabies. In Rabies. Edited by Campbell JB, Charlton. Boston: Kluver. Academic Publishers; 1988:101-150.

3. Baer GM: The natural history of rabies. Boca Raton: CRC Press; 1991.

4. Fraser GC, Hooper PT, Lunt RA, Gould AR, Gleeson LJ, Hyatt AD, Russell GM, Kattenbelt JA: Encephalitis caused by a Lyssavirus in fruit bats in Australia. Emerg Infect Dis 1996, 2(4):327-331.

5. Hanna JN, Carney IK, Smith GA, Tannenberg AE, Deverill JE, Botha JA, Serafin IL, Harrower BJ, Fitzpatrick PF, Searle JW: Australian bat Lyssavirus infection: a second human case, with a long incubation period. Med J Aust 2000, 172(12):597-599.

6. World Health Organization: World survey of rabies, 22: for years 1984-85. Geneva: WHO-Rabies-87.198; 1986.

7. Finnegan CJ, Brookes SM, Johnson N, Smith J, Mansfield K, Keene VL, McElhinney LM, Fooks AR: Rabies in North America and Europe. J R Soc Med 2002, 95(1):9-13.

8. Organización Panamericana de la Salud: Boletín Vigilancia Epidemiológica de la Rabia en las Américas, Volume XXXIV. Rio de Janeiro; 2002:40.

9. Dias RA, Garcia RC, Silva DF, Amaku M, Ferreira Neto JS, Ferreira F: Estimativa de populações canina e felina domiciliadas em zona do Estado de São Paulo. Rev Saúde Públ 2004, 38(4):565-570.

10. Grisi-Filho JHH, Amaku M, Dias RA, Montenegro Netto H, Paranhos NT, Mendes MCNC: Use of geographic information systems in rabies vaccination campaigns. Rev Saúde Públ 2008, 42(6):1005-1011.

11. Albas A, Zoccolaro PT, Rosa TZ, Cunha SEM: Diagnóstico laboratorial da raiva na região oeste do Estado de São Paulo. Rev Soc Bras Med Trop 2005, 38(6):493-495.

12. Baltazard M, Bahmanyar M, Ghodssi, Sabeti A, Gajdusek C, Rouzbeh E, 5: Essai pratique du sérum antirabique chez les mordus par loups enragés. Bull World Health Organ 1955, 13:747-772.

13. World Health Organization: Expert Committee on Rabies. Geneva; 1991. Report.

14. Smith JS, Yager PA, Baer GM: A rapid fluorescent focus inhibition test (RFFIT) for determining rabies virus-neutralizing antibodies. In Laboratory techniques in rabies. Edited by Meslin FX, Kaplan NM, Koprowsky H. Geneva: WHO; 1998:181-192.

15. Kotait I, 7: Raiva humana causada pela variante 3 Desmodus rotundus. Instituto Pasteur (Past In) 2003, 4:3.

16. Zalan E, Wilson C, Pukitis D: A microtest for the quantitation of rabies virus neutralizing antibodies. J Biol Stand 1979, 7(3):213-220.

17. Favoretto SR, Carrieri ML, Tino MS, Zanetti CR, Pereira OAC: Simplified fluorescent inhibition microtest for the titration of rabies neutralizing antibodies. Rev Inst Med Trop São Paulo 1993, 35(2):171-175.

18. Rigo L, Honer MR: Titulação de anticorpos contra o vírus da raiva em cães, em Campo Grande, MS, na aampanha anti-rábica de 2003. Rev Soc Bras Med Trop 2006, 39(6):553-555.

19. Almeida MF, Aguiar EAC, Martorelli LAF, Presotto D, Brandão MM, Pereira OAC: Resposta imune humoral de cães à vacina inativada, de cérebro de camundongos lactentes, utilizada nas campanhas anti-rábicas no Brasil. Rev Saúde Públ 1997, 31:502-507.

20. Aubert MFA: Pratical significance of rabies antibody in cats and dogs. Rev Sci Techn Off Int Epiz 1992, 11(3):735-760.

21. Genaro G: Gato doméstico: futuro desafio para controle da raiva em áreas urbanas? Pesq Vet Bras 2010, 30(2):186-189.

doi:10.1186/1678-9199-19-17

Cite this article as: Albas et al: Humoral immune response in dogs and cats vaccinated against rabies in southeastern Brazil. Journal of Venomous Animals and Toxins including Tropical Diseases 2013 19:17. 